\section{SEBARAN HABITAT ANGGREK ALAM DI TAMAN NASIONAL LORE LINDU}

Taman Nasional Lore Lindu (TNLL) merupakan salah satu Taman Nasional di Indonesia yang terdapat di Provinsi Sulawesi Tengah dengan luas $229.177,5$ ha. Kawasan konservasi terbesar di Sulawesi Tengah ini mendapat banyak predikat atau julukan karena potensi dan keunikan yang dimilikinya, diantaranya adalah sebagai cagar biosfer (tahun 1977 oleh MAB-UNESCO), nominasi sebagai "World Heritage Site" (UNESCO), kawasan burung endemik (EBA"Endemic Bird Area"), pusat keanekaragaman tumbuhan (CPD"Center of Plant Diversity"), serta sebagai wilayah ekologi global 200 (Global 200 Ecoregions-G200 ES) yang dikembangkan oleh WWF-US (Olsen \& Dinerstein 1998) melalui pertimbangan karena kawasan tersebut memiliki contoh-contoh ekosistem yang luar biasa yang menyimpan kekayaan spesies dengan endemisitas spesies yang tinggi, keunikan taksonomi yang tinggi dan fenomena ekologi serta evolusi yang luar biasa (TNC/BTNLL, 2002).

Dari beberapa laporan menyatakan bahwa kawasan ini menyimpan pesona berbagai jenis anggrek beserta karakteristik habitat serta habitusnya (Ramadanil, 2010 ; Nasrun, 2011). Hasil pengamatan jenis-jenis anggrek pada daerah dataran rendah, hutan pegunungan bawah, hutan pegunungan, hutan pegunungan atas di Taman Nasional Lore Lindu semua dapat diidentifikasi. Hasil identifikasi tersebut, diketahui terdapat 45 jenis anggrek dengan kelimpahan 242 individu. Jenis-jenis anggrek yang teridentifikasi dari masing-masing daerah pengamatan diamati berdasarkan keadaan habitat tumbuh anggrek, komposisi atau variasi jenis, jumlah individu serta penyebaran anggrek yang ditemui.
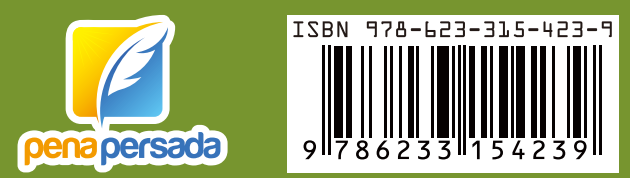

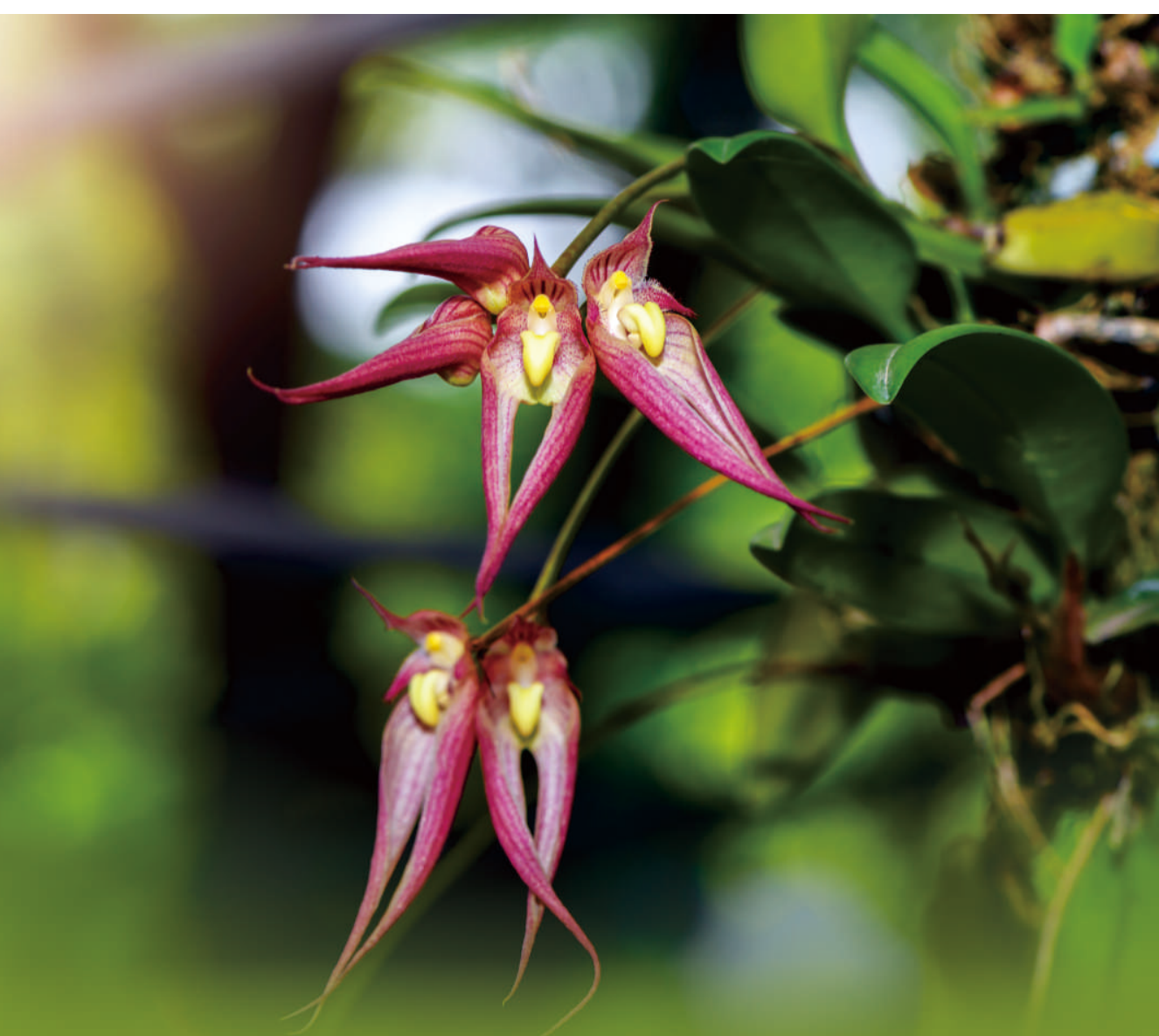

Muhammad Syaifuddin Nasrun
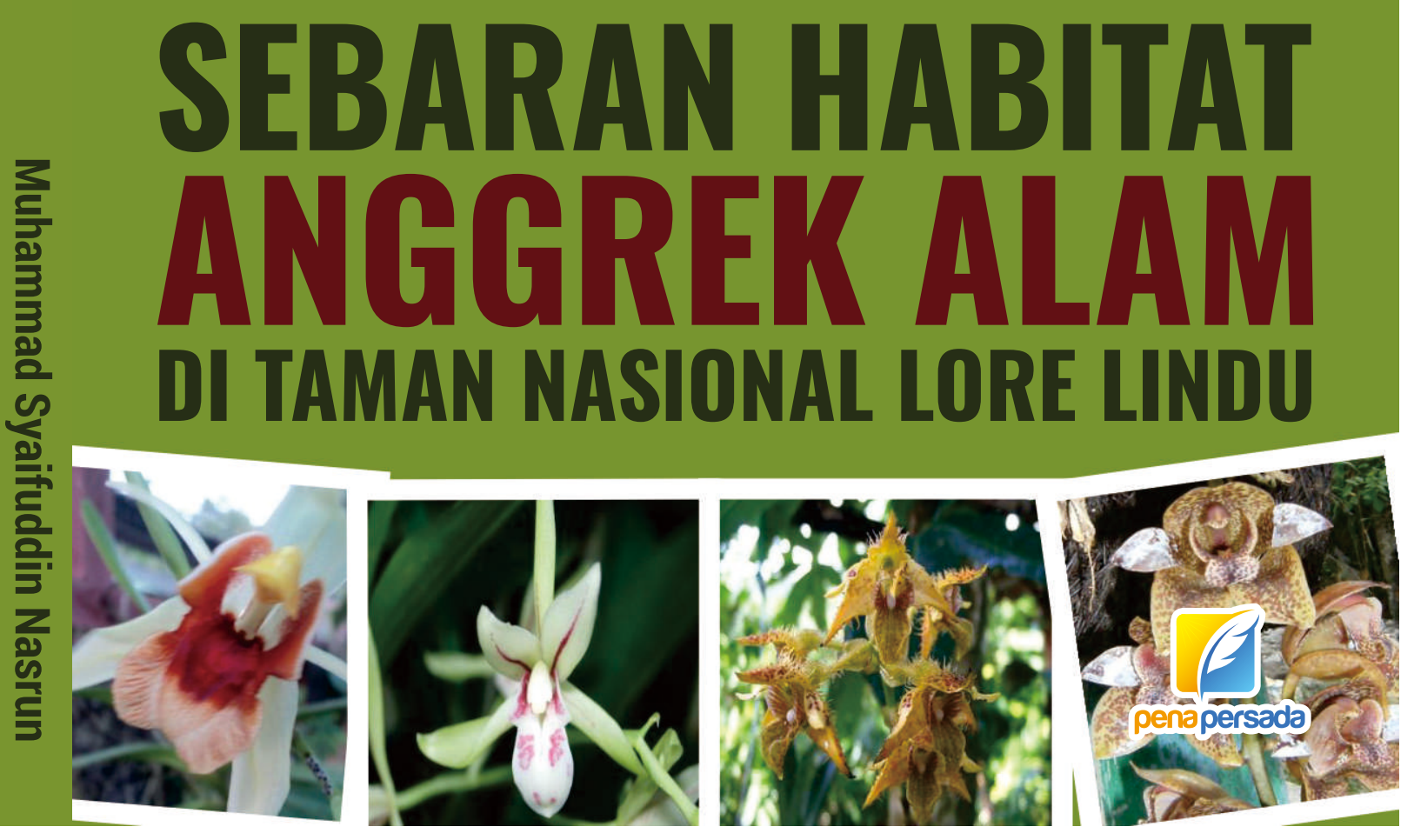


\section{SEBARAN HABITAT ANGGREK ALAM DI TAMAN NASIONAL LORE LINDU}

Muhammad Syaifuddin Nasrun

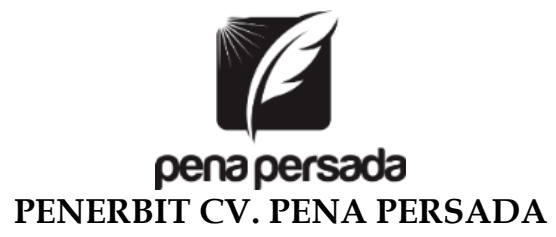




\title{
SEBARAN HABITAT ANGGREK ALAM \\ DI TAMAN NASIONAL LORE LINDU
}

\author{
Penulis: \\ Muhammad Syaifuddin Nasrun
}

ISBN : 978-623-315-423-9

Editor:

Wiwit Kurniawan

Design Cover :

Retnani Nur Briliant

Layout :

Hasnah Aulia

\section{Penerbit CV. Pena Persada \\ Redaksi :}

Jl. Gerilya No. 292 Purwokerto Selatan, Kab. Banyumas Jawa Tengah

Email : penerbit.penapersada@gmail.com

Website : penapersada.com Phone : (0281) 7771388

\section{Anggota IKAPI}

All right reserved

Cetakan pertama : 2021

Hak Cipta dilindungi oleh undang-undang. Dilarang memperbanyak karya tulis ini dalam bentuk apapun tanpa izin penerbit 


\section{KATA PENGANTAR}

Segala puji senantiasa kita panjatkan kehadirat Allah Swt, atas segala rahmat dan karunianya, akhirnya penulis dapat menyelesaikan penyusunan buku yang berjudul "SEBARAN HABITAT ANGGREK ALAM DI TAMAN NASIONAL LORE LINDU". Saya menyadari bahwa tanpa bantuan dan bimbingan dari berbagai pihak sangatlah sulit bagi saya untuk menyelesaikan karya ini. Oleh karena itu, saya mengucapkan banyak terima kasih pada semua pihak yang telah membantu penyusunan buku ini. Sehingga buku ini bisa hadir di hadapan pembaca.

Keanekaragaman jenis anggrek alam di Taman Nasional Lore Lindu belum banyak diungkapkan, namun berbagai habitatnya terancam kelestariannya karena aktivitas manusia. Dalam buku ini membahas mengenai keanekaragaman jenis anggrek pada berbagai tipe hutan yang berbeda ketinggian, serta faktor lingkungan dan jenis tumbuhan inangnya. Penelitian dalam buku ini dilakukan dari bulan Januari sampai Juni 2019 di empat tempat yang berbeda tipe hutannya berdasarkan elevasi, yaitu Bobo (hutan dataran rendah), Kamarora (hutan pegunungan bawah), Kalimpa'a (hutan pegunungan), dan Rorekautimbu (hutan pegunungan atas) dalam kawasan Taman Nasional Lore Lindu (TNLL). Hasil penelitian dalam buku ini menunjukan bahwa terdapat 45 jenis anggrek (26 marga), yang terdiri dari 36 bersifat epifit dan 9 jenis terrestrial dengan total 242 individu. Pada hutan dataran rendah dan hutan pegunungan atas ditemukan 22 jenis, hutan pegunungan bawah 12 jenis dan pada hutan pegunungan 16 jenis anggrek. Indek keaneragaman jenis $\left(\mathrm{H}^{\prime}\right)$ di semua lokasi tergolong rendah nilainya $<1$. Kemerataan jenis (e) anggrek pada empat lokasi tergolong sedang pada hutan dataran rendah 0,908 , hutan pegunungan rendah 0,731.

Penulis menyadari bahwa buku ini masih jauh dari kesempurnaan. Oleh karena itu kritik dan saran yang membangun sangat dibutuhkan guna penyempurnaan buku ini. Akhir kata saya berharap Allah Swt berkenan membalas segala kebaikan semua pihak yang telah membantu. Ucapan terima kasih penulis sampaikan pula kepada: 
1. Prof Dr Ramadanil M.Si

2. Dr Ir. Hj Wardah Mfsc

3. Dr Ir. Sri Ningsih Mallobasang M.P

Akhinya penulis mengucapkan banyak terima kasih yang setulus-tulusnya kepada semua pihak yang banyak membantu penulis. Penulis mengucapkan terima kasih atas kitikan, masukan, dan saran yang sangat berarti, sehingga layak untuk penulis gunakan sebagai dasar menyusun disertasi ini.

Palu, Juni 2020

Penulis 


\section{DAFTAR ISI}

KATA PENGANTAR iii

DAFTAR ISI $\mathrm{V}$

BAB I PENDAHULUAN

A. Taman Nasional Lore Lindu 1

B. Keanekaragaman jenis anggrek

2

BAB II JENIS ANGGREK

A. Jenis-jenis Anggrek Taman Nasional Lore Lindu 4 DAFTAR PUSTAKA 76 
SEBARAN HABITAT ANGGREK ALAM DI TAMAN NASIONAL LORE LINDU 


\section{BAB I \\ PENDAHULUAN}

\section{A. Taman Nasional Lore Lindu}

Taman Nasional Lore Lindu (TNLL) resmi ditetapkan sebagai salah satu Taman Nasional di Indonesia pada tanggal 23 Juni 1999 setelah mengalami beberapa perubahan status kawasan dan pengelolaannya. Pada awalnya TNLL merupakan penggabungan dari beberapa kawasan lindung meliputi: Suaka Margasatwa Lore Kalamanta (SK. Mentan No.522 /Kpts/Um/1973); Hutan Wisata dan Hutan Lindung Danau Lindu (SK. Mentan No.46/Kpts/Um/1978); dan Suaka Margasatwa Lore Lindu (SK. Mentan No. 101/Kpts/Um/1981). Dasar keputusan penetapan kawasan tersebut sebagai TNLL adalah deklarasi penggabungan kawasan lindung sebagai taman nasional pada kongres taman nasional sedunia di Denpasar Bali tahun 1982, melalui SK Mentan No. 376/Mentan/X/1982. Selanjutnya ditunjuk oleh Menteri Kehutanan melalui SK.Menhut No.593/Kpts-II/1993 dengan luas 229.000 hektar merupakan hutan warisan dunia dan juga sebagai cagar biosfer dunia. (BTNLL, 2010).

Keputusan tersebut dijadikan dasar untuk melakukan tata batas definitif dan dikukuhkan Menteri Kehutanan dan Perkebunan SK. Menhutbun No.464 /Kpts-II/1999 tanggal 23 Juni 1999 dengan luas 217.991,18 hektar. Adapun pengelolaannya berdasarkan peraturan Menteri Kehutanan No. P.03./Menhut-II/2007, sejak 1 Februari 2007, diserahkan kepada Balai Besar Taman Nasional Lore Lindu. Kawasan yang luasnya 217.991.18 hektar terletak di wilayah Kabupaten Sigi dan Kabupaten Poso, Provinsi Sulawesi Tengah (BTNLL, 2010). 


\section{B. Keanekaragaman jenis anggrek}

Tumbuhan dari famili Orchidaceae sangat terkenal karena kecantikan dan keindahan bunganya serta kekompleksan dari mekanisme penyerbukan (Rohimah dkk., 2018). Selain itu, bunganya juga sangat berwarna warni dan beraroma harum (Kaiser 1993; Senghas 1993) dan ukuran vegetatif bervariasi dari mikroskopis seperti pada Platystele dan Bulbophyllum hingga berukuran panjang merambat seperti pada Vanilla dan berukuran raksasa seperti pada marga Grammatophyllum dan Cyrtopodium (Pridgeon, 1996).

Anggrek memiliki harapan yang cerah karena potensi keragaman genetiknya sangat tinggi, dikembangkan terutama dibidang hortikultura. Hal itu didasari karena adanya jenisjenis anggrek yang merupakan bahan induk untuk mendapatkan hibrida-hibrida baru dan diperkirakan terdapat sekitar 5.000 jenis anggrek alam di Indonesia (Soediono, 2011). Sebagian besar jenis anggrek tersebut hidup di berbagai tipe ekosistem terutama dalam hutan-hutan kawasan konservasi, seperti Cagar Alam, Suaka Marga Satwa, Taman Nasional dan berbagai kawasan hutan lainnya.

Taman Nasional Lore Lindu (TNLL) merupakan salah satu Taman Nasional di Indonesia yang terdapat di Provinsi Sulawesi Tengah dengan luas 229.177,5 ha. Kawasan konservasi terbesar di Sulawesi Tengah ini mendapat banyak predikat atau julukan karena potensi dan keunikan yang dimilikinya, diantaranya adalah sebagai cagar biosfer (tahun 1977 oleh MAB-UNESCO), nominasi sebagai "World Heritage Site" (UNESCO), kawasan burung endemik (EBA-"Endemic Bird Area"), pusat keanekaragaman tumbuhan (CPD-"Center of Plant Diversity"), serta sebagai wilayah ekologi global 200 (Global 200 Ecoregions-G200 ES) yang dikembangkan oleh WWF-US (Olsen \& Dinerstein 1998) melalui pertimbangan karena kawasan tersebut memiliki contoh-contoh ekosistem yang luar biasa yang menyimpan kekayaan spesies dengan endemisitas spesies yang tinggi, keunikan taksonomi yang tinggi dan fenomena ekologi serta evolusi yang luar biasa (TNC/BTNLL, 2002). 
Keanekaragaman jenis anggrek alam di kawasan ini belum banyak diungkapkan. Namun, dari beberapa laporan menyatakan bahwa kawasan ini menyimpan pesona berbagai jenis anggrek beserta karakteristik habitat serta habitusnya (Ramadanil, 2010 ; Nasrun, 2011). Di sisi lain, berbagai habitat di kawasan ini juga terancam kelestariannya oleh berbagai aktivitas manusia. 


\section{BAB II JENIS ANGGREK}

\section{A. Jenis-jenis Anggrek Taman Nasional Lore Lindu}

Hasil pengamatan jenis-jenis anggrek pada daerah dataran rendah, hutan pegunungan bawah, hutan pegunungan, hutan pegunungan atas di Taman Nasional Lore Lindu semua dapat diidentifikasi. Hasil identifikasi tersebut, diketahui terdapat 45 jenis anggrek dengan kelimpahan 242 individu. Jenis-jenis anggrek yang teridentifikasi dari masing-masing daerah pengamatan diamati berdasarkan keadaan habitat tumbuh anggrek, komposisi atau variasi jenis, jumlah individu serta penyebaran anggrek yang ditemui. Adapun jenis-jenis anggrek yang dijumpai di Taman Nasional Lore Lindu sebagai berikut.

\section{Aerides odoratum Lour}

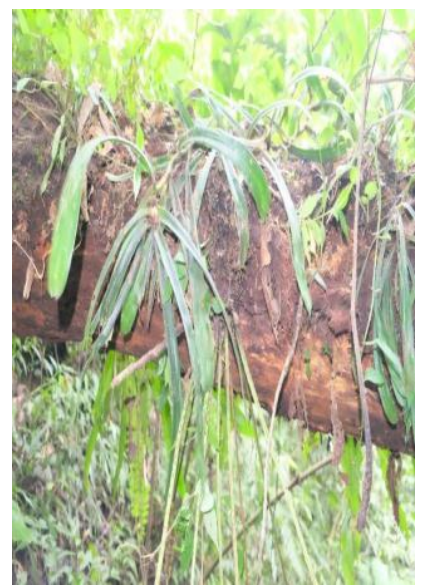

Sumber: (Hasil Pengamatan, 2019) Sumber: (Nasrun, 2011)

Gambar 5.1 Aerides odoratum Lour

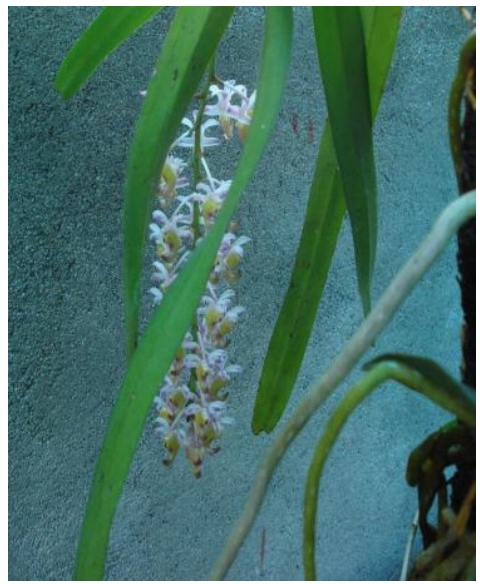




\section{Sinonim:}

Aerides latifolia., A. cornuta Roxb., A. virens Lindl., A. suaveolens B1., A. flavida

Lindl. (Puspitaningtyas, 2003).

Pertelaan:

Habitus: Anggrek Aerides odoratum Lour atau disebut juga anggrek kuku macan karena bentuk bibirnya yang bertaji dan melengkung berupa anggrek epifit yang tumbuh secara monopodial. Daun: berjumlah sekitar 7 helai, tebal dan kaku, ujung terbelah dua membulat, tidak memiliki tangkai daun dan langsung menyelimuti batang, panjang 25,5--28 cm, lebar 2,2-2,8 cm. Bunga: pembungaan muncul dari ketiak daun, panjang tangkainya $32 \mathrm{~cm}$ dengan jumlah 24 kuntum bunga dengan lebar 2,5 cm, berwarna dasar putih bertitik-titik ungu, di setiap sudut perhiasan bunganya ada noktah berwarna ungu muda. Bibir berbelah tiga dan menyatu menutupi tugunya, sedangkan tajinya (spur) melengkung ke depan seperti kuku dengan ujung yang runcing (Puspitaningtyas, 2003). Saat dijumpai anggrek ini dalam keadaan tidak berbunga dan masa berbunga bulan Desember dan Januari.

Habitat dan penyebarannya: anggrek ini dijumpai di daerah hutan pegunungan (danau kalimpa'a) tumbuh secara epifit pada pohon tumbang Haleka (Castanopsis accuminatisima (Blume) Rehder) dengan ketinggian tempat 1.660,25 m dpl, suhu sekitarnya $19^{\circ} \mathrm{C}$, intensitas penyinaran diperkirakan sebesar $10 \%$, dan kelembaban berkisar $87 \%$ dengan jumlah individu yang dijumpai hanya satu. 
2. Agrostophyllum majus J.J.Sm.

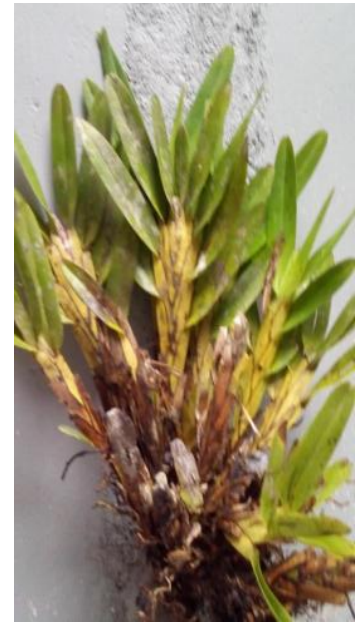

Sumber:

(Hasil Pengamatan, 2019) 2011)

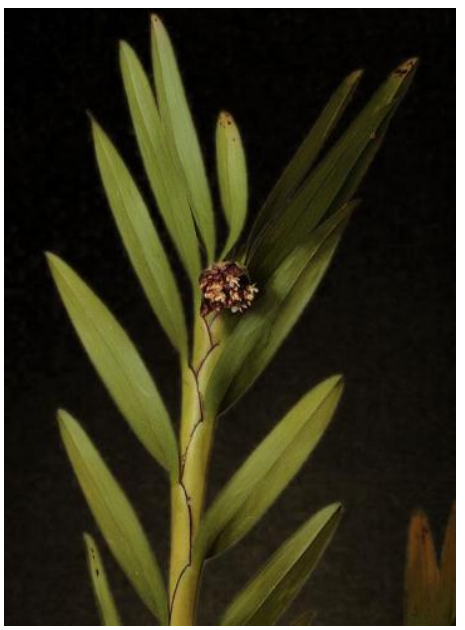

Sumber: (Nasrun,

Gambar 5.2 Agrostophyllum majus J.J.Sm.

\section{Sinonim:}

Agrostophyllum saccatum Ridl. (Puspitaningtyas, 2005)

Pertelaan:

Habitus: Ciri khas marga Agrostophyllum umumnya mempunyai rangkaian bunga di ujung batang (terminal) yang tersusun membulat dengan beberapa kuntum bunga yang berukuran kecil dan rata-rata berwarna putih (Puspitaningtyas, 2003; Mallombasang, 2019).

Habitus: termasuk anggrek epifit dengan pertumbuhan batangnya sympodial, batangnya tertutup pangkal daun. Daun: berbentuk pedang runcing di ujung, tipis berwarna hijau muda, berukuran $17,2 \times 1,5 \mathrm{~cm}$ dan tersusun rapat.

Habitat dan penyebarannya: anggrek ini dijumpai di daerah hutan dataran rendah (Desa Bobo) di ketinggian 857,08 mdpl. dan daerah hutan pegunungan (Danau Kalimpa'a) pada ketinggian 1.652,38,1.661,62, dan 1668,99 mdpl., tumbuh secara epifit di pohon lebanu (Neonauclea intercontinentalis Bakh.f. Ridsdale) dan Pakis (Alsophila celebica (Blume) Mett) dalam 
keadaan tidak berbunga, suhu sekitarnya $19--23,3^{\circ} \mathrm{C}$, intensitas penyinaran 10--22,1\%, dan kelembaban berkisar $84--88 \%$. Marga Agrostophyllum tumbuh subur pada percabanganpercabangan pohon pada kondisi hutan yang membentuk kanopi yang rapat (Sulistiarini, 2009).

\section{Acanthephippium javanicum Bl.}

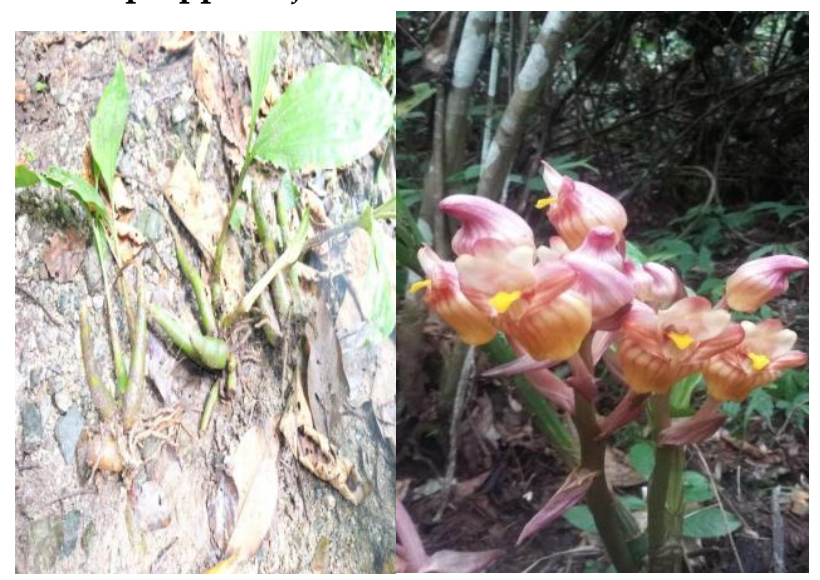

Sumber: (Hasil Pengamatan, 2019)

Sumber: (TNLL 2019)

Gambar 5.3 Acanthephippium javanicum B1

\section{Sinonim: -}

\section{Pertelaan:}

Habitus: berupa anggrek terrestrial, pertumbuhan batang sympodial berakar tebal. umbi semu rapat satu sama lain berukuran hingga $25 \mathrm{~cm}$ panjangnya, mendukung 2--4 helai daun. Daun: daun berbentuk oblong dengan beberapa lipatan dan ujung meruncing, panjang 20x5 cm. Bunga: 3--6 kuntum yang muncul dari setiap umbi semuanya. Pada saat mekar lebarnya 3--5 cm, perhiasannya berwarna dasar kuning pucat hingga merah muda dengan garis tebal merah pada bagian interiornya. Bibir cuping sampingnya tegak membulat, cuping tengah ujungnya melancip berukuran lebih sempit. Di antara kedua cuping samping berbentuk gerigi halus berwarna kuning. Masa berbunga bulan Desember dan Januari di jumpai di lapangan. 
Habitat dan penyebarannya: anggrek ini dijumpai di daerah hutan dataran rendah (Desa Bobo), pada ketinggian 836,69 mdpl dan di daerah hutan pegunungan bawah (Kamarora) di ketinggian tempat 1.014,60 mdpl. Anggrek ini hidup di tanah (terrestrial), saat dijumpai suhu sekitarnya $23,7--24,3^{\circ} \mathrm{C}$ dengan intensitas penyinaran sekitar 10--32\% dan kelembaban berkisar $91 \%$ serta penyebaran individu yang sangat sedikit.

\section{Appendicula celebica (Schltr.) Schltr.}

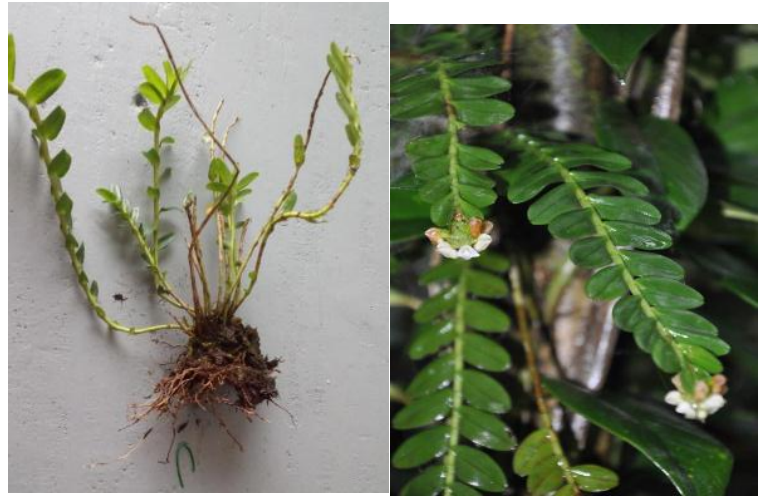

Sumber: (Hasil Pengamatan, 2019)

Sumber: (TNLL, 2019)

Gambar 5.4 Appendicula celebica (Schltr.) Schltr

\section{Sinonim:}

Podochillus congenera BL. (Puspitaningtyas, 2003)

\section{Pertelaan:}

Habitus: berupa anggrek epifit, pertumbuhan batang sympodial. Batang : berukuran panjang antara 15 hingga $25 \mathrm{~cm}$ dan tidak bercabang. Daun: berukuran 9x8 mm, berwarna hijau tua tersusun rapat. Bunga: pada saat mekar lebarnya $8 \mathrm{~mm}$, pembungaan di ujung batang terdiri 2--4 kuntum. Kelopak maupun mahkota

berwarna putih dan tugu berwarna kehijauan. Bibir: dari bagian ujung hingga tengahnya terlipat ke belakang sehingga ujungnya menyentuh bagian tengah bibir.

Habitat dan penyebarannya: anggrek ini dijumpai di daerah hutan dataran rendah (Desa Bobo), anggrek ini hidup secara epifit pada batang pohon Palaquium quercifolium (de Vriese) 
Burck (Kumea vatu, Wana), ketinggian 895,11 mdpl, suhu sekitarnya $25^{\circ} \mathrm{C}$ dengan intensitas penyinaran sekitar 29,7\% serta kelembaban 78\%. Penyebaran individu yang sangat sedikit.

\section{Arundina graminifolia (D.Don) Hochr.}

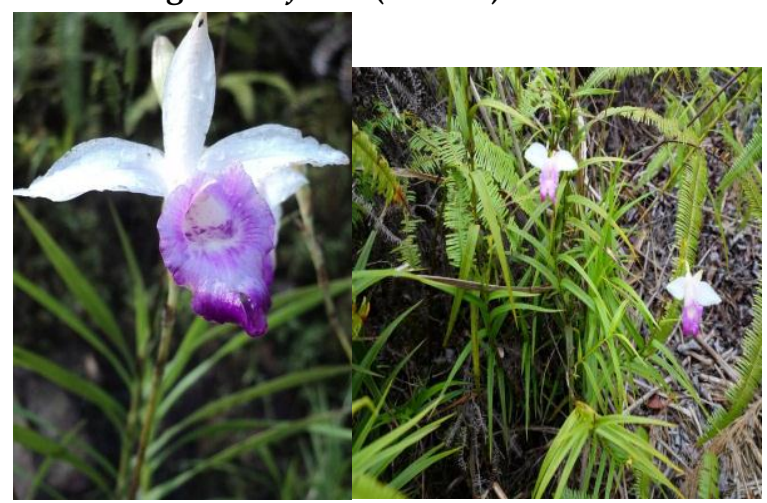

Sumber: (Hasil Pengamatan, 2019) Sumber: (Nasrun, 2011) Gambar 5.5 Arundina graminifolia (D.Don) Hochr.

\section{Sinonim:}

Bletia graminifolia D. Don. Hoch., Arundina speciosa Bl., A. chinensis Bl., A. densa Lindl., A. revolute Hook. F. (Puspitaningtyas, 2003).

\section{Pertelaan:}

Habitus: Arundina graminifolia (D.Don) Hochr. disebut juga anggrek bambu, termasuk anggrek terrestrial mempunyai tipe pertumbuhan batang sympodial, tumbuh merumpun dengan ketinggian tanaman 1--2 $\mathrm{m}$ dan beruas-ruas, sering disebut dengan nama anggrek bambu karena bentuknya yang mirip dengan bambu. Daun: daun seperti pita, agak tipis, kasar, beralur, kedudukan daun berselang seling, jarak antar daun agak jarang, pangkal daun memeluk batang serta ujung daun meruncing, berukuran 15--30 cm x 0,75-2,5 cm. Saat dijumpai di lapangan anggrek sedang berbunga. Pembungaan: beberapa bunga keluar bergerombol tetapi hanya 1--2 kuntum yang mekar kedudukan bunga di terminal berdiameter $4--9 \mathrm{~cm}$, sepal lonjong ujungnya runcing warna putih, petalnya lonjong 
bagian pinggir bergelombang dan berwarna putih, bibir berwarna ungu terang, memanjang dan tepinya bergelombang. Masa berbunga antara bulan Januari dan April (Latif, 1953; Mallombasang, 2019).

Habitat dan penyebarannya: anggrek ini tumbuh menyebar di daerah hutan dataran rendah (Desa Bobo) pada ketinggian 824,98 mdpl, daerah hutan pegunungan (Danau Kalimpa'a) ketinggian 1664,81--1669,46 mdpl, hutan pegunungan atas (jalur rorekatimbu) di ketinggian 2.061,19 mdpl, hidup di tanah (terrestrial) dalam keadaan berbunga. Suhu sekitarnya 18,6-$28,8^{\circ} \mathrm{C}$, intensitas penyinaran sebesar $10-30 \%$ dengan kelembaban berkisar $82--83 \%$, jumlah individu yang banyak.

\section{Bulbophyllum biflorum Teijsm. \& Binn.}
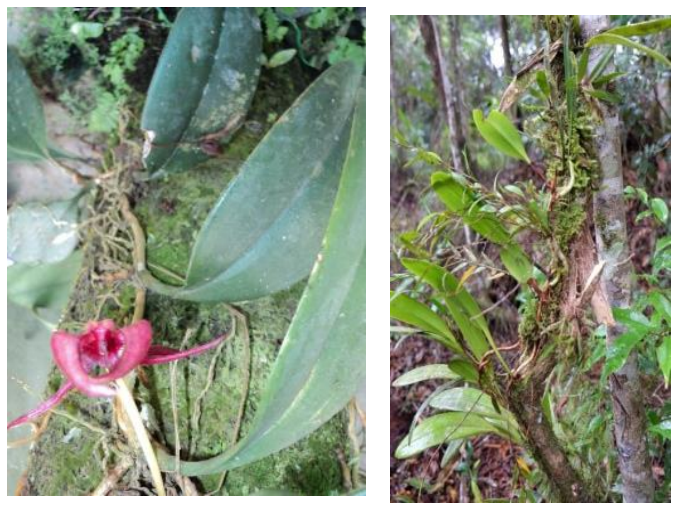

Sumber: (Nasrun, 2011)

Sumber: (Hasil Pengamatan, 2019)

Gambar 5.6 Bulbophyllum biflorum Teijsm. \& Binn.

\section{Sinonim:}

Cirrhopetalum biflorum Teijsm. \& Binn (Puspitaningtyas, 2003)

\section{Pertelaan:}

Habitus: merupakan anggrek epifit, tumbuh merayap di batang pohon. Umbi semu: agak pendek, bersegi berukuran 3,5 x 1,5 $\mathrm{cm}$. Daun: berbentuk lanset berukuran $12 \times 6 \mathrm{~cm}$, agak tebal dan kaku. Pembungaan: muncul dari tunas akar rimpang (rhizome), panjang $11 \mathrm{~cm}$ dan bunganya berpasangan. Bunga: 
berwarna merah muda berbintik merah tua. Kelopak punggungnya berukuran kecil berbentuk seperti helm yang menelungkup, kelopak samping berukuran $7,5 \mathrm{~cm}$ menyatu di ujungnya. Mahkotanya berukuran kecil. Bibir berbentuk seperti lidah, lebar di pangkal dan meruncing di ujungnya, berwarna merah tua. Saat ditemukan di lapangan anggrek ini dalam keadaan berbunga. Masa berbunga bulan September dan Maret.

Habitat dan penyebarannya: anggrek ini tumbuh merumpun dengan individu yang sedikit pada daerah hutan pegunungan rendah (Kamarora) di ketinggian 852 mdpl serta daerah hutan pegunungan atas (jalur Rorekatimbu) dijumpai pada batang pohon tumbang dan Pohon Belanti (Homalanthus populneus (Geissler) Pax) yang berlumut pada ketinggian 2.010,58 dan 2.010,92 mdpl. Suhu pada saat anggrek ini dijumpai sekitar 15-$24,3^{\circ} \mathrm{C}$ dan intensitas penyinaran sekitar $10 \%$, serta kelembaban berkisar $90--91 \%$.

\section{Bulbophyllum echinolabium J.J.S.}

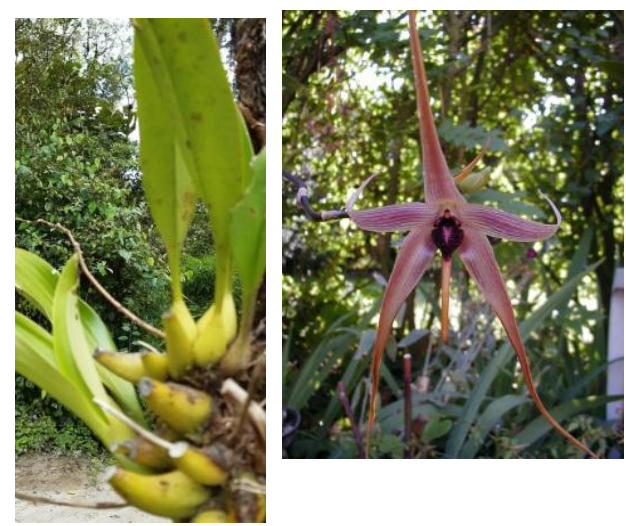

Sumber: (Nasrun, 2011)

Sumber: (Hasil Pengamatan, 2019)

Gambar 5.7 Bulbophyllum echinolabium J.J.S. 


\section{Sinonim: -}

\section{Pertelaan:}

Habitus: Bulbophyllum echinolabium J.J.S. anggrek berbibir landak termasuk anggrek epfit yang mempunyai tipe pertumbuhan batang sympodial, umbi membesar ke atas lonjong atau bulat telur berukuran $6 \mathrm{~cm}$, agak pipih berwarna hijau dan tiap umbi berdaun satu helai. Daun: berbentuk bulat panjang, tebal, berwarna hijau berukuran $33 \times 5,5 \mathrm{~cm}$ dan ujungnya agak runcing serta daun beralur. Pembungaan: muncul dari pangkal umbi atau rimpang, dengan tangkai yang pendek. Bunga: kelopak berukuran panjang $8 \times 5 \mathrm{~cm}$ berbentuk segitiga ujungnya runcing, melipat, tampak urat memanjang berwarna kuning keunguan dan mahkotanya berukuran $6 \mathrm{~cm}$, warna sama dengan kelopaknya. Bibir sebelah bawah lebar, mudah bergerak, ujungnya panjang dan bulat sebelah ke atas berwarna hitam kemerahan (Latif, 1953; Mallombasang, 2019). Masa berbunga bulan Desember dan bulan Januari dijumpai di lapangan.

Habitat dan penyebarannya: anggrek ini tumbuh merumpun pada pohon Haleka (Castanopsis accuminatisima [Blume] Rehder) dengan individu yang sedikit pada daerah hutan pegunungan atas pada ketinggian 1.847,19 mdpl. Suhu pada saat anggrek ini dijumpai berkisar $19^{\circ} \mathrm{C}$ dan intensitas penyinaran sekitar $10 \%$, serta kelembaban berkisar 85\%. Oleh Latif (1953) Bulbophyllum enchinolobium J.J.S. di Indonesia dijumpai di Sulawesi terutama di Kabupaten Donggala. 
8. Bulbophyllum lobbii Lind.

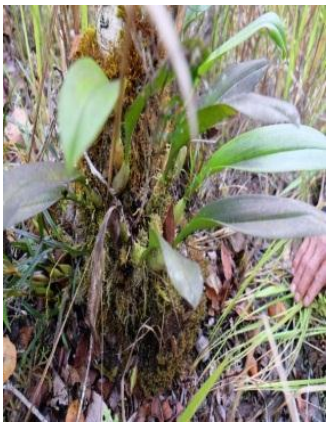

Sumber:

(Hasil

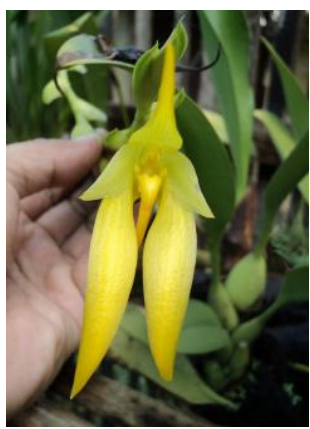

2019)

Pengamatan,

Sumber: (Nasrun, 2011)

Gambar 5.8 Bulbophyllum lobbii Lind.

\section{Sinonim:}

Sestochilos uniflorum Breda., Sarcopodium lobii Lindl., Bulbophyllum henshallii Hort., Bulbophyllum siamensis Rchb. F. (Puspitaningtyas, 2003).

\section{Pertelaan:}

Habitus: termasuk anggrek epifit mempunyai tipe pertumbuhan batang sympodial, umbi semunya lonjong atau bulat telur dan agak licin memanjang berukuran $5 \mathrm{~cm}$, agak pipih berwarna hijau dan tiap umbi berdaun satu helai. Daun: berbentuk bulat panjang, tebal, berwarna kuning kehijauan berukuran 20x6 $\mathrm{cm}$ dan ujungnya agak membelah dua. Pembungaan: muncul dari pangkal umbi atau rimpang, dengan tangkai yang pendek. Bunga: bergaris tengah $6,5 \mathrm{~cm}$, berwarna kuning cerah dan kelopaknya panjang, runcing dan ujungnya terlipat berukuran 5,5x1,2 cm. Daun mahkota panjang, agak lebar, runcing sebelah menyebelah dan panjang $4,5 \times 0,5 \mathrm{~cm}$. Bibir kecil, agak runcing dan berwarna kuning cerah. Masa berbunga bulan Desember dan Januari dijumpai di lapangan.

Habitat dan penyebarannya: anggrek ini tumbuh merumpun pada pohon Tombe (Syzigium accuminatisimum (Blume) DC) dengan individu yang sedikit pada daerah hutan dataran 